\title{
Article \\ Efficacy of Post-Emergence Herbicides against Important Weeds of Sugarcane in North-East Thailand
}

\author{
Phitsanu Aekrathok, Patcharin Songsri $\mathbb{D}^{\mathrm{D}}$, Nuntawoot Jongrungklang ${ }^{(D)}$ and Santimaitree Gonkhamdee * $\mathbb{D}$ \\ Department of Agronomy, Faculty of Agriculture, Khon Kaen University, Khon Kaen 40002, Thailand; \\ Phitsanu_a@kkumail.com (P.A.); patcharinso@kku.ac.th (P.S.); nuntjo@kku.ac.th (N.J.) \\ * Correspondence: gsanti@kku.ac.th
}

Citation: Aekrathok, P.; Songsri, P.; Jongrungklang, N.; Gonkhamdee, S. Efficacy of Post-Emergence

Herbicides against Important Weeds of Sugarcane in North-East Thailand. Agronomy 2021, 11, 429. https:// doi.org/10.3390/agronomy11030429

Academic Editors: Ilias Travlos, Nicholas Korres and Rafael De Prado

Received: 22 January 2021

Accepted: 22 February 2021

Published: 26 February 2021

Publisher's Note: MDPI stays neutral with regard to jurisdictional claims in published maps and institutional affiliations.

Copyright: (c) 2021 by the authors. Licensee MDPI, Basel, Switzerland. This article is an open access article distributed under the terms and conditions of the Creative Commons Attribution (CC BY) license (https:/ / creativecommons.org/licenses/by/ $4.0 /)$.

\begin{abstract}
Weeds represent a significant problem in Thailand's sugarcane production. The various cycles of sugarcane cultivation result in degrees of weed severity in which each species requires a different weed control method, the most popular of which is the post-emergence herbicide method. However, sugarcane farmers often use incorrect rates, and operators' safety is missing or applications are not selective, causing toxicity and interrupted growth of sugarcane. The effects of post-emergence herbicide types, time, and application rates are presented herein, through an experiment in Northeast Thailand, conducted in a randomized complete block design (RCBD) with four replications. The herbicides paraquat and ametryn were evaluated, with paraquat being more effective, yet resulting in higher toxicity and lower yield components. We may conclude through our experiments that ametryn and paraquat can be applied only once for sugarcane at the tillering stage and at rates of 540 and $2400 \mathrm{~g}_{\text {ai ha }}{ }^{-1}$, respectively. These rates were lower than the recommended rates, which represented the minimum doses necessary to control Thailand's dominant weed species like Brachiaria distachya (L.) Stapf., Dactyloctenium aegyptium (L.) P.B., Praxelis clematidea R.M King \& H. Rob and Pennisetum polystachion (L.) Schult. Consequently, the adequate control of weeds is a rather case-specific situation and therefore each weed species should be taken into account.
\end{abstract}

Keywords: weed management; major weed; weed control; phytotoxicity

\section{Introduction}

Weeds are one of the most damaging obstructions in sugarcane cultivation systems; the severity of which is dependent on weed density and the age of the sugarcane [1]. Weeds compete with sugarcane for resources; such as water, nutrients, sunlight, and space; whereby increased weed density results in reduced sugarcane yield [2]. In parts of Ethiopia, such losses were reported to be as high as 70 to $84 \%$ [3]. In the USA, weed-crop competition at 3, 6, and 9 weeks after planting resulted in sugarcane yield losses of 78, 51, and 42\%, respectively [4,5]. In Thailand, an absence of weeding within the first four months of sugarcane grown in the wet season resulted in yield losses greater than $70 \%$ [6]. In each location, the weed species differed, due to several factors; such as soil texture, soil $\mathrm{pH}$, seasonal changes, and the selection and usage of chemical fertilizers and herbicides [7-9]. Therefore, preferred methods of weed control exist within species, due to the sugarcane planting system and crop cycle.

Thailand is the second-largest exporter of sugar after Brazil, generating more than three billion dollars (USD) in revenue per year. In 2017, Thailand's sugarcane production area encompassed approximately 1 million hectares, with an average yield of 69 tonnes ha $^{-1}$ and a total yield of 103 million tonnes [10]. Currently, the Thai government has developed a policy to increase sugarcane areas consistent with production potential, as well as to adapt areas that are not suitable for planting rice (Oryza sativa L.). More than half of the country's sugarcane production area is located in the Northeast region, where 60 to $70 \%$ consists of the Khon Kaen 3 (KK3) variety, due to its ability to grow in loamy sandy soil, 
drought-tolerance, and resistance to white-leaf cane disease [11]. Thailand's sugarcane crop cycle is dependent on both the variety, as well as the region of production. In the Northeast region, the most popular period for planting cane is between October to November, referred to as the late-rainy season; whereas the Central and Eastern regions plant cane between November to February [12]. Each region has a different weed species spectrum as a result of different environmental conditions, in which each environment creates a unique level of weed infestation.

Sugarcane growth relies on soil moisture for germination. As soil humidity at the soil surface gradually decreases within the Northeast region, weeds fail to germinate, resulting in relatively fewer problems within the sugarcane harvest. However, some weed species are drought-tolerant and can germinate in low-moisture soil, which results in rapid growth during the rainy season, thereby becoming a dominant weed species. Some weed species, such as crowfoot grass (Dactyloctenium aegyptium (L.) P.B.) and Canada goldenrod (Solidago canadensis L.) have been reported to be highly invasive in many regions, due to their remarkable drought-tolerant behavior [13-15].

In Northeast Thailand, weed development occurs within the first three months of sugarcane production, in which germination begins with the start of rain precipitation. Suwanarak [16] and Kalro [17] reported the necessity of weeding during sugarcane production's tillering stage, in the first three to four months. The presence of weeds in this period greatly affects the development of millable, tiller growth, stalk population, and the competition for sunlight and nutrients. Farmers typically practice weed control two to three times throughout the season, depending on weed density [18]. In the late-rainy season of sugarcane cultivation, farmers typically perform weed control twice in preparation for the upcoming rainy season, when the sugarcane is in the stalk elongation stage (six-months-old). Their weed control practices include hand and mechanized weeding, as well as the more popular use of post-emergence herbicides, as herbicides are efficient, easy to use, and low in cost and labor.

Ametryn and paraquat are the most popular and often used herbicides used to control weeds in Thailand's sugarcane fields, although both herbicides are not registered in many parts of the world. Ametryn is a pre- or early-post-emergence herbicide, and it can move within the plant structure $[19,20]$, having an effect on plants in the process of electron transfer from photosystem II, resulting in plants' symptoms beginning with interveinal leaves chlorosis and yellowing of leaves within 2-3 days, followed by further chlorosis and necrosis, while paraquat is a post-emergence herbicide that is classified as a nonselective contact herbicide, and it affects plants in the process of electron transfer from the photosystem $\mathrm{I}$, causing reactive oxygen species (ROS) including $\mathrm{H}_{2} \mathrm{O}_{2}, \mathrm{O}_{2}{ }^{-}$, which can cause cell membrane toxicity or photosynthesis, resulting in exposed areas of the plant rapidly wilting $[21,22]$. However, despite their intended benefits, they are often misused, resulting in equally damaging weed devastation [23] and reduced crop yields [24]. In Iran, brown beetle grass (Diplachne fusca (L.) Beauv.) is a weed species not effectively controlled by current post-emergence herbicides, which greatly reduces sugarcane yields [25]. Takim et al. [26] later reported the varied weed control of ametryn in several weed species; however, some species, like cogon grass [Imperata cylindrica (L.) Raeuschel.] and goose grass [Eleusine indica (L.) Gaertn.], could not be controlled. Similarly, Silva et al. [27] reported that different sugarcane varieties have different tolerance levels to ametryn + sodium triflusysulfuron applications. According to Simões et al. [28], each sugarcane variety may respond differently to the same herbicide at the same rate. Pavani et al. [29] also reported that the application of paraquat at various rates resulted in different biomass weight losses in each tested sugarcane variety, in which increases in the herbicide rate caused corresponding decreases in biomass weight up to 18 to $30 \%$. Studies within Thailand have yet to report weed species dominance and weed control via post-emergence herbicides upon the KK3 sugarcane variety. 
Thus, the study herein aimed to evaluate weed species dominance and weed control of post-emergence herbicides on KK3 sugarcane in the late-rainy season, as well as to inform farmers of the careful use of herbicides.

\section{Materials and Methods}

\subsection{Site Description and Experimental Design}

Our study of post-emergence herbicides upon the weed control of the KK3 sugarcane variety was conducted in upland fields in the late-rainy season from 27 December 2017 to 24 December 2018, Khon Kaen province, Thailand [16 $29^{\prime} 34.7^{\prime \prime}$ N $102^{\circ} 42^{\prime} 24.8^{\prime \prime}$ E and $180 \mathrm{~m}$ a.s.l. (Experiment I), and $16^{\circ} 29^{\prime} 32.9^{\prime \prime} \mathrm{N} 102^{\circ} 42^{\prime} 29.1^{\prime \prime} \mathrm{E}$ and $180 \mathrm{~m}$ a.s.l. (Experiment II)]. Sugarcane clones, incorporating three buds layered double stalk per row, were used in Experiment I and Experiment II. Experiment I contained $31.5 \mathrm{~m}^{2}$ in each plot, whereas Experiment II contained $25.2 \mathrm{~m}^{2}$ in each plot. In Experiment I, the herbicides were applied to sugarcane in each plot with a single application at the sugarcane tillering stage (threemonths-old) on 27 March 2018 (90 days after planting; DAP). In Experiment II, herbicides were applied at the tillering stage on 27 March 2018 (90 DAP) and stalk elongation stage (six-months-old) on 28 June 2018 (183 DAP) (Figure 1). Both experiments were laid out in randomized complete block design (RCBD) with four replications, comparing two of the most often used post-emergence herbicides: Ametryn (POSTECH ${ }^{\circledR} 80 \% \mathrm{WP}$, Chia Tai Company, Bangkok, 10260, Thailand) and paraquat (GRAMOXONE ${ }^{\circledR} 20 \% \mathrm{~W} / \mathrm{V}$ (ion), Syngenta Company, Samutprakarn, 10280, Thailand). Ametryn was applied at 2400, 2700, 3000 (recommend rate), 3300, and $3600 \mathrm{~g}$ ai ha $^{-1}$; and paraquat was applied at 480, 540,600 (recommend rate), 660, and $720 \mathrm{~g}_{\text {ai ha }}{ }^{-1}$ in each plot followed the experimental design. Each application was then compared to both the weedy (non-weeding) and weed-free (hand weeding) treatments. The herbicides were applied over the tops of the sugarcane and weeds with a $15 \mathrm{~L}$ knapsack sprayer fitted with a flooding fan nozzle, at a rate of $500 \mathrm{~L} \mathrm{ha}^{-1}$ of water. Spray speed was controlled to ensure even coverage within each treatment. For controlling of uniformity of herbicide application, the herbicides were applied at low wind speed and spray solutions were thoroughly agitated each time a new solution was prepared, and immediately prior to application, to control the error.

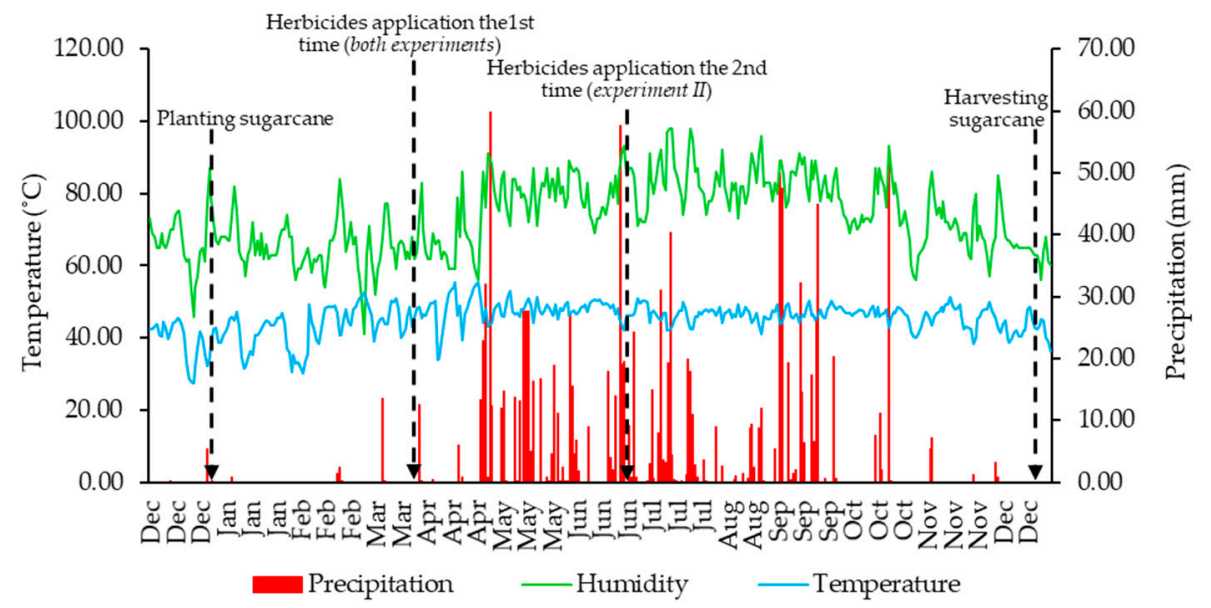

Figure 1. Experiment duration and weather information (2017-2018).

\subsection{Data Collection}

Weather data were gathered from the meteorological station nearest to the experimental field (Meteorological Center, Upper Northeast Thailand). Average rainfall was $1250 \mathrm{~mm}$, the average temperature was 17 to $36{ }^{\circ} \mathrm{C}$, and relative humidity was 62 to $84 \%$ (Figure 1); which are deemed suitable for sugarcane cultivation [30].

Herbicide efficiency of weed control was visually assessed at 1, 3, 7, 14, 21, and 30 days after application (DAA) on a scale of 0 (no weed control) to 100 (complete weed control) 
following the protocol of Frans and Talbert [31]. Weed recovery was visually recorded as the totality of weeds in each plot that began to sprout new leaves (with no sign of toxicity greater than $50 \%$ of the entire plot). The days from herbicide application to weed recovery were also recorded. Weeds were randomly collected from two quadrats $\left(0.25 \mathrm{~m}^{2}\right)$ in each plot above and below the soils' surface at before application (BA), and 30, 60, 90, 120, and 150 DAA. Weed species were identified through a random sampling of weeds in each plot following the method of Noda et al. [32]. Weed density were counted in all treatments of each herbicide application, weights were measured, and their respective biomasses were obtained via drying in a hot-air oven at $80^{\circ} \mathrm{C}$ for $72 \mathrm{~h}$.

Phytotoxicity of herbicides on sugarcane was visually assessed at 1, 3, 7, 14, 21, and 30 DAA using a scale of $0 \%$ (no crop reduction or injury) to 100\% (complete crop destruction) as described by Frans and Talbert [31]. Sugarcane recovery was recorded using the same weed recovery method. Yield component data (360 DAP) were gathered by cutting the sugarcane stalks above ground, cutting the inflorescences, pulling out the leaves, and then weighing the cane stands to estimate cane yield in tonnes $\mathrm{ha}^{-1}$. Sugarcane was randomly selected from six stalks in each plot, and commercial cane sugar (CCS) was calculated using the following [33] formula (Equation (1)).

$$
C C S=\frac{3 P}{2}\left(1-\frac{F+5}{100}\right)-\frac{B}{2}\left(1-\frac{F+3}{100}\right)
$$

$P=$ pol at $20^{\circ} \mathrm{C}, B=$ brix at $20^{\circ} \mathrm{C}$, and $F=$ fiber percent.

\subsection{Statistical Analysis}

The data analysis of variance was used according to the experiment design to examine differences in treatment effect including weed control, weed recovery, sugarcane toxicity, sugarcane recovery, yield, and yield component. The data were subjected to statistical analysis using Statistix ${ }^{\circledR} 10$ (1985-2013) program (Analytical Software, Tallahassee, FL, USA), and treatment mean differences were separated using the LSD at $5 \%$ probability. No data transformation was used on weed density and weed biomass.

\section{Results}

3.1. Effects of Post-Emergence Herbicides in Weed Control

3.1.1. Weed Control and Weed Recovery in Experiment I

The application of paraquat showed greater weed control than the ametryn application at every assessment period. Both herbicides showed the highest weed control at 3 to 7 DAA, with sharp decreases of each until 30 DAA (Figure 2). The application of ametryn in various rates showed no significant differences $(p<0.05)$ in weed control (Table 1). Conversely, the applications of paraquat in various rates were not significant at BA, 3, 7, and 14 DAA; but highly significant at 21 and 30 DAA. The paraquat application at the rate of $540 \mathrm{~g}$ ai ha $^{-1}$ demonstrated relatively high weed control at $21 \mathrm{DAA}$, whereas the $720 \mathrm{~g}$ ai ha ${ }^{-1}$ rate produced effective weed control in every assessment period (Table 1). 


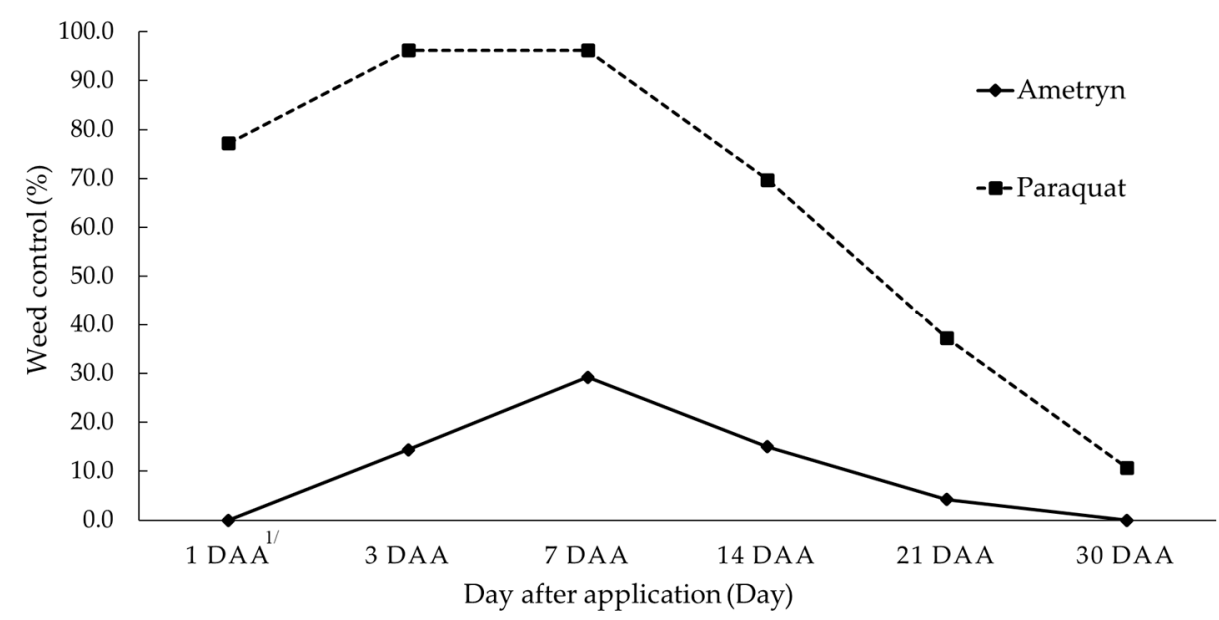

Figure 2. Effects of ametryn and paraquat applications on weed control at 1, 3, 7, 14, 21, and 30 DAA in Experiment I. ${ }^{1 /}$ days after application.

Table 1. Effects of ametryn and paraquat applications at various rates on weed control at 1, 3, 7, 14, 21, and 30 DAA; and weed recovery in Experiment I.

\begin{tabular}{|c|c|c|c|c|c|c|c|}
\hline \multirow{2}{*}{ Treatments } & \multicolumn{6}{|c|}{ Weed Control (\%) } & \multirow{2}{*}{$\begin{array}{l}\text { Weed Recovery } \\
\text { (Day) }^{2 /}\end{array}$} \\
\hline & $1 \mathrm{DAA}^{1 /}$ & 3 DAA & 7 DAA & 14 DAA & 21 DAA & 30 DAA & \\
\hline \multicolumn{8}{|c|}{ Ametryn (g ai ha $\left.{ }^{-1}\right)$} \\
\hline 2400 & 0.0 & 16.3 & 28.8 & 12.5 & 2.5 & 0.0 & 12 \\
\hline 2700 & 0.0 & 13.3 & 35.0 & 15.0 & 3.8 & 0.0 & 13 \\
\hline 3000 & 0.0 & 12.5 & 28.8 & 18.8 & 2.5 & 0.0 & 12 \\
\hline 3300 & 0.0 & 12.5 & 25.0 & 15.0 & 5.0 & 0.0 & 11 \\
\hline 3600 & 0.0 & 17.5 & 28.8 & 13.8 & 7.5 & 0.0 & 12 \\
\hline F-test & ns & $\mathrm{ns}$ & $\mathrm{ns}$ & $\mathrm{ns}$ & ns & ns & ns \\
\hline $\mathrm{CV} \%$ & 0.0 & 32.8 & 35.5 & 37.1 & 42.6 & 0.0 & 20.7 \\
\hline \multicolumn{8}{|c|}{ Paraquat (g ai ha ${ }^{-1}$ ) } \\
\hline 480 & 76.3 & 95.0 & 93.8 & 67.5 & $30.0 \mathrm{~b}^{3 /}$ & $6.3 c$ & $18 \mathrm{~b}$ \\
\hline 540 & 75.0 & 97.5 & 97.5 & 73.8 & $37.5 \mathrm{a}$ & $11.3 \mathrm{ab}$ & $21 \mathrm{a}$ \\
\hline 600 & 82.5 & 95.0 & 95.0 & 66.3 & $37.5 \mathrm{a}$ & $10.0 \mathrm{bc}$ & $20 \mathrm{ab}$ \\
\hline 660 & 75.0 & 93.8 & 95.0 & 71.3 & $38.8 \mathrm{a}$ & $11.3 \mathrm{ab}$ & $20 \mathrm{ab}$ \\
\hline 720 & 77.5 & 100.0 & 100.0 & 70.0 & $42.5 \mathrm{a}$ & $15.0 \mathrm{a}$ & $21 \mathrm{a}$ \\
\hline F-test & $\mathrm{ns}^{4 /}$ & ns & ns & ns & $* * 5 /$ & ** & $* 6 /$ \\
\hline $\mathrm{CV} \%$ & 9.0 & 6.7 & 5.9 & 9.3 & 9.8 & 24.4 & 6.7 \\
\hline
\end{tabular}

1/ Days after application, ${ }^{2 /}$ total days before the weeds began to produce new leaves, ${ }^{3 /}$ means in the same lowercase letter are not significantly different by LSD at $p<0.05,4 /$ not significant at $p<0.05,{ }^{5 /}$ significant at $p<0.01$, and ${ }^{6 /}$ significant at $p<0.05$.

The paraquat applications resulted in slow weed recovery compared to the ametryn applications (Table 1). Paraquat applications at the rates of 540,600,660, and $720 \mathrm{~g} \mathrm{a} \mathrm{ha}^{-1}$ were considered as delayed weed recovery, which is considered appropriate for use in sugarcane fields to control weed competition in the early stages of cane development. Ametryn showed no significant differences across all application rates. Therefore, a single herbicide application was recommended at the rates of $2400 \mathrm{~g}$ ai ha ${ }^{-1}$ for ametryn and $540 \mathrm{~g}$ ai ha ${ }^{-1}$ for paraquat for tillering stage of sugarcane that sugarcane could recovery at stalk elongation stage.

\subsubsection{Weed Control and Weed Recovery in Experiment II}

Herbicides were applied twice at the tillering and stalk elongation stages of the sugarcane. Paraquat proved more effective in weed control than ametryn for tillering and 
stalk elongation stage on sugarcane at every assessment period (Figure $3 \mathrm{a}, \mathrm{b}$ ). The first application of ametryn at 3 and 7 DAA at the rates of 3300 and $3600 \mathrm{~g}$ ai ha ${ }^{-1}$ showed $33.8,49.5 \%$, and $37.5,55.0 \%$ weed control, respectively, greater than that of the 2400 and $2700 \mathrm{~g}$ ai ha ${ }^{-1}$ rate (Figure 3a). Similarly, the paraquat applications at the rates of 660 and $720 \mathrm{~g}$ ai ha ${ }^{-1}$ were superior to the 540 and $600 \mathrm{~g}^{\text {ai ha }}{ }^{-1}$ rates (Figure $3 \mathrm{~b}$ ). Weed control percentages were affected immediately after application, which were more drastic in paraquat (65 to $80 \%$ ) versus the slowly affected ametryn. However, in the second application, the effects of both herbicides were lower (Figure $3 a, b$ ). The results indicated that a second application was unnecessary, and provided minimal benefits for weed control in the now early-mid rainy season (Figure 1).
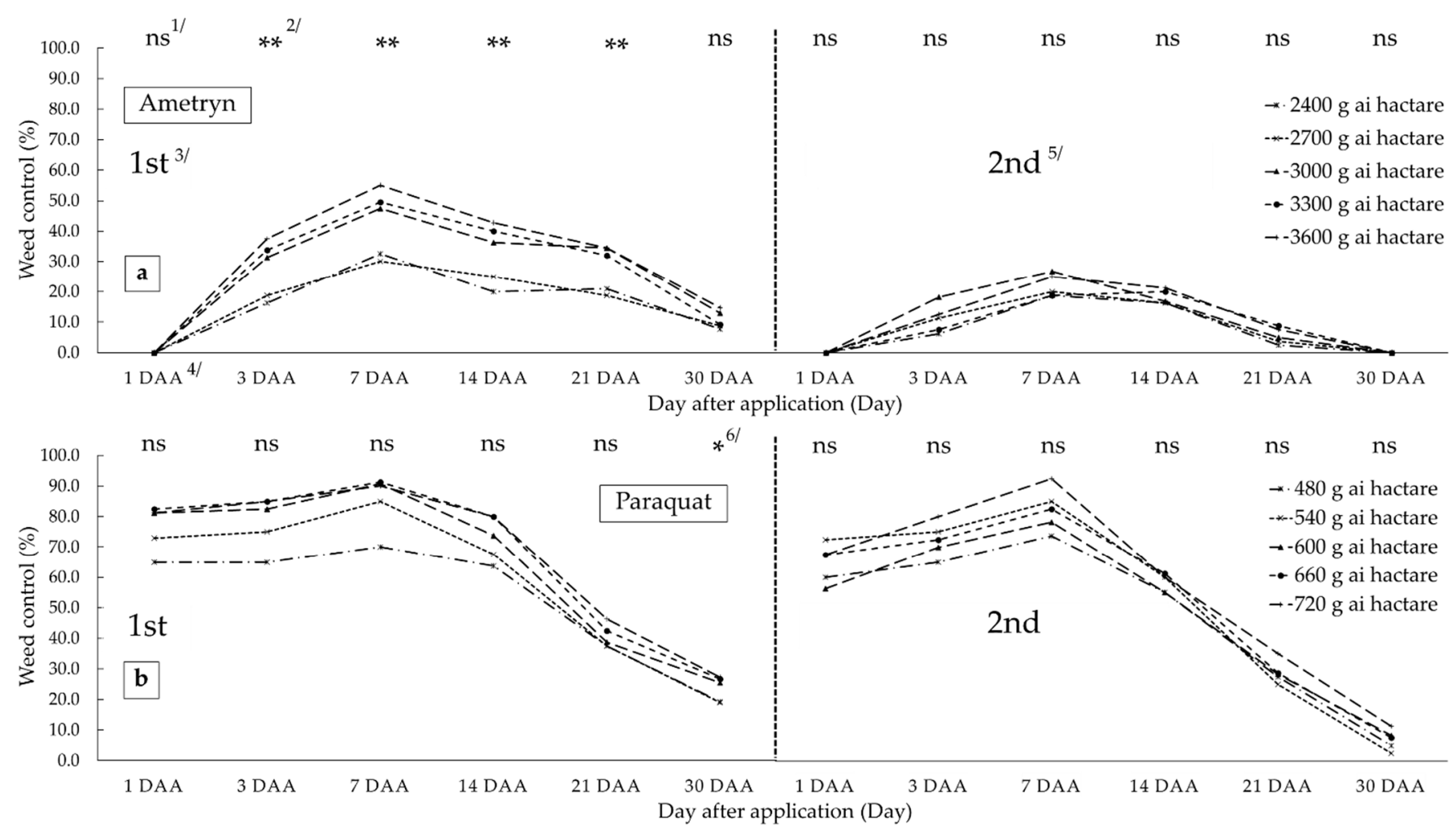

Figure 3. Effects of ametryn and paraquat applications on weed control percentage at various rates in the first and second applications: (a) Ametryn applications, (b) paraquat applications. ${ }^{1 /}$ Not significant, ${ }^{2 /}$ significant at $p<0.01,{ }^{3 /}$ herbicide application the first time (left), $4 /$ days after application, ${ }^{5 /}$ herbicide application the second time (right), and ${ }^{6 /}$ significant at $p<0.05$.

Weed recovery was slowest in the paraquat applications in the tillering stage of sugarcane; where the rate 600,660 , and $720 \mathrm{~g}$ ai ha ${ }^{-1}$ were not statistically different (Table 2). The ametryn application in various rates to the tillering and stalk elongation stages of sugarcane and paraquat application in the stalk elongation stage of sugarcane were not statistically different at each assessment period. However, the first application had a high effect of herbicide compared to the second application. However, the number of recovery days was longer with paraquat than ametryn (Table 2). More days of weed recovery are significant in the control of weeds for the upcoming dry season before vegetative re-growth in the next rainy season. The number of days for weed recovery for ametryn and paraquat was 16 and 18 days at the first herbicide application, respectively. Therefore, the recommended rates of application of ametryn and paraquat, dependent on both weed control and weed recovery, for tillering stage of sugarcane, were 3000,3300 , and $3600 \mathrm{~g} \mathrm{ai} \mathrm{ha}^{-1}$ for ametryn, $600 \mathrm{~g}$ ai ha ${ }^{-1}$ for paraquat. 
Table 2. Effects of ametryn and paraquat applications at various rates on weed recovery in Experiment II.

\begin{tabular}{|c|c|c|}
\hline \multirow{2}{*}{ Treatments } & \multicolumn{2}{|c|}{ Weed Recovery (Days) ${ }^{1 /}$} \\
\hline & 1st Application (Tillering Stage) & 2nd Application (Stalk Elongation Stage) \\
\hline \multicolumn{3}{|c|}{ Ametryn (g ai ha $\left.{ }^{-1}\right)$} \\
\hline 2400 & 15 & 12 \\
\hline 2700 & 15 & 13 \\
\hline 3000 & 17 & 12 \\
\hline 3300 & 17 & 14 \\
\hline 3600 & 18 & 12 \\
\hline F-test & ns & ns \\
\hline $\mathrm{CV} \%$ & 9.4 & 19.8 \\
\hline \multicolumn{3}{|c|}{ Paraquat (g ai ha ${ }^{-1}$ ) } \\
\hline 480 & $14 \mathrm{~b}^{2 /}$ & 17 \\
\hline 540 & $15 \mathrm{~b}$ & 19 \\
\hline 600 & $20 \mathrm{a}$ & 18 \\
\hline 660 & $20 \mathrm{a}$ & 18 \\
\hline 720 & $22 \mathrm{a}$ & 19 \\
\hline F-test & $* * 3 /$ & $\mathrm{ns}^{4 /}$ \\
\hline $\mathrm{CV} \%$ & 7.0 & 10.8 \\
\hline
\end{tabular}

1/ Total days before the weeds began to produce new leaves, ${ }^{2 /}$ means in the same letters are not significantly different by LSD at $p<0.05,{ }^{3 /}$ significant at $p<0.01$, and ${ }^{4 /}$ not significant.

\subsubsection{Weed Density and Weed Biomass}

In Experiment I, the applications of paraquat resulted in lower weed density and weed biomass than those of the ametryn applications (Figure $4 a, b$ ). The weed density decreased sharply after paraquat was applied, whereas decreases occurred slowly after the ametryn applications. Weed density were highly significant between the ametryn and paraquat applications at 30 days post-application. The applications of paraquat at $30,60,90,120$, and 150 DAA produced similar weed density, which were less than that of the application at BA. Contrastingly, ametryn produced slowly decreasing density, the slowest being recorded at 120 DAA. Weed biomasses were not significantly different between paraquat and ametryn within the first period after the herbicide was applied. Both treatments resulted in increasing biomass levels, which were highest 90 DAA, due to the weed recovery after each herbicide application (Figure $4 \mathrm{~b}$ ). Ametryn produced slightly higher weed biomass levels due to its faster weed recovery (Table 2). The effectiveness of both herbicides showed gradual declines, which disappeared within 30 to 60 DAA. Any further decreases were attributed to the sugarcane canopy. We also noted that lower weed density may have been a result of competing weed species within each weed density (Figure 4a,b).

In Experiment II, the application of ametryn resulted in fewer weed density than the paraquat applications, which decreased sharply after application (Figure 4c,d). Second applications (90 DAA) proved insignificant in their effects upon weed density in both herbicide applications. Weed biomasses resulting from both herbicides gradually decreased, primarily in the second applications, and particularly for the ametryn treatment. After the second application, both herbicides produced reduced weed biomasses at 120 DAA (Figure $4 \mathrm{~d}$ ); however, paraquat was observed to control weed biomass better than that of the ametryn throughout the evaluation period. 

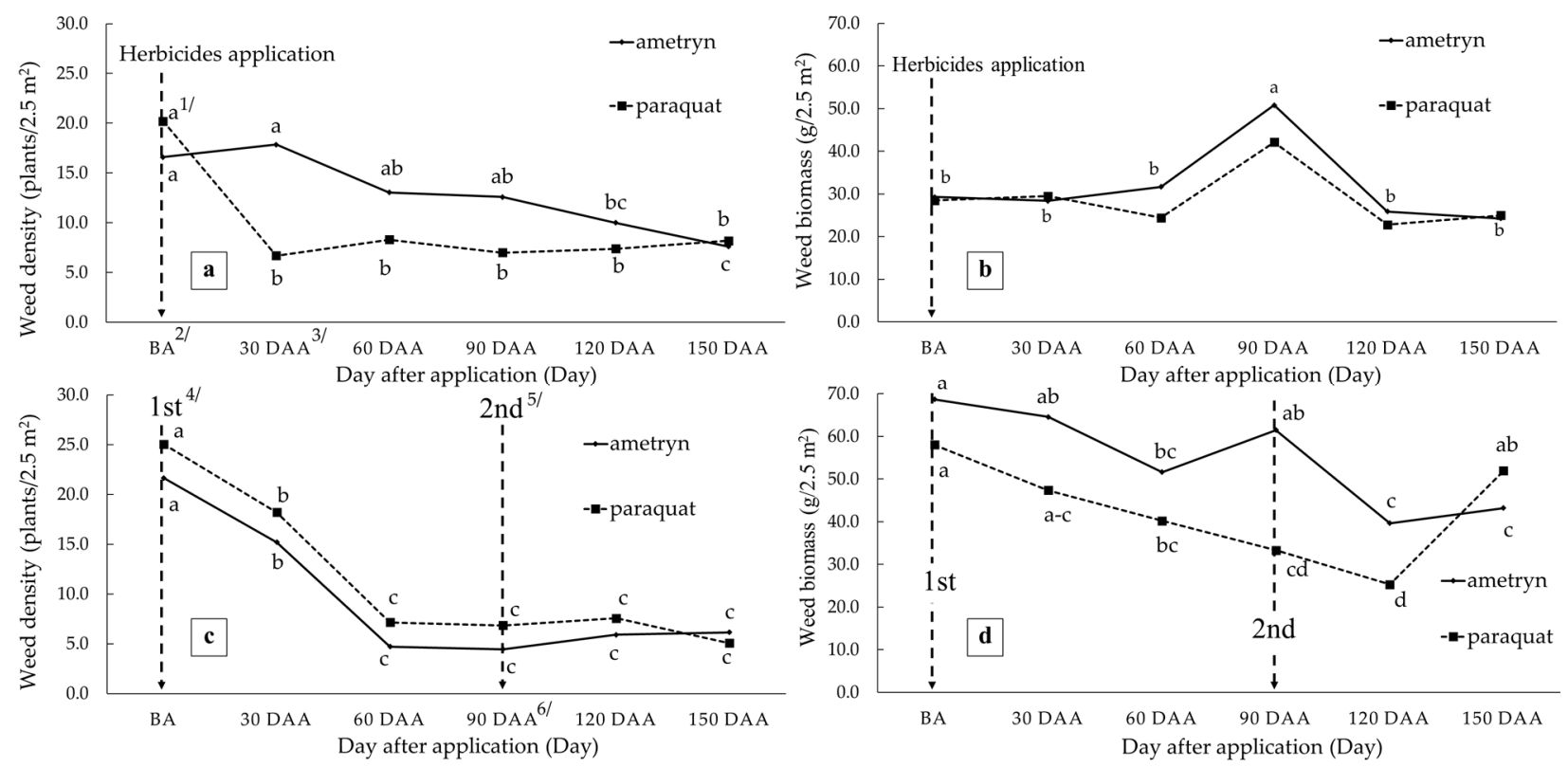

Figure 4. Effects of ametryn and paraquat applications in Experiment I and Experiment II on weed density and weed biomass; (a) weed density in Experiment I, (b) weed biomass in Experiment I, (c) weed density in Experiment II, and (d) weed biomass in Experiment II. ${ }^{1 /}$ Means in the same lowercase letter within the same herbicide line are not significantly different by LSD at $p<0.05,2 /$ before application, ${ }^{3 /}$ days after application, ${ }^{4 /}$ herbicide application the first time, $5 /$ herbicide application the second time, and ${ }^{6 /}$ before second time application.

\subsubsection{Weed Species Richness Occurring in Experiments I and II}

In Experiment I, thirty-three weed species were present in the field, consisting of 23 annual weed species (70\%) and 10 perennial weed species (30\%). Based on their morphological classifications, 23 species $(70 \%)$ were broad-leaved, seven weed species $(21 \%)$ were grasses, and three weed species (9\%) were sedges (Figures S1 and S2). Five weeds species were identified as dominant and problematic for sugarcane growth: D. aegyptium; Praxelis clematidea R.M King and H. Rob; Pennisetum polystachion (L.) Schult; Brachiaria distachya (L.) Stapf.; and Digitaria ciliaris (Retz.) Koel (Figure 5). In comparisons of herbicide applications before (BA) and after (30 DAA), three of the five weed species showed a high number of weeds and weed biomass at 30 DAA, while $B$. distachya and D. ciliaris produced lower levels (Figure 5). Additionally, increased herbicide application rates produced decreases in the number of weeds and weed biomass, particularly in the paraquat applications. However, weed control efficiency varied across several weeds species, in which ametryn, for example, was unable to control the number of D. aegyptium at the rate and weed biomass of P. clematidea (Figure 5). Some weed species were low in number after herbicide application, yet were high in biomass, as decreased applications reduced species competition, as evidenced in D. aegyptium and P. clematidea at $30 \mathrm{DAA}$, the paraquat applications produced low weed number, yet higher biomasses (Figure 5). A higher the number of weeds were observed in the ametryn treatment of $P$. polystachion. Our results indicated significant values in weed control and competition, as well as weed habitat maturity. 

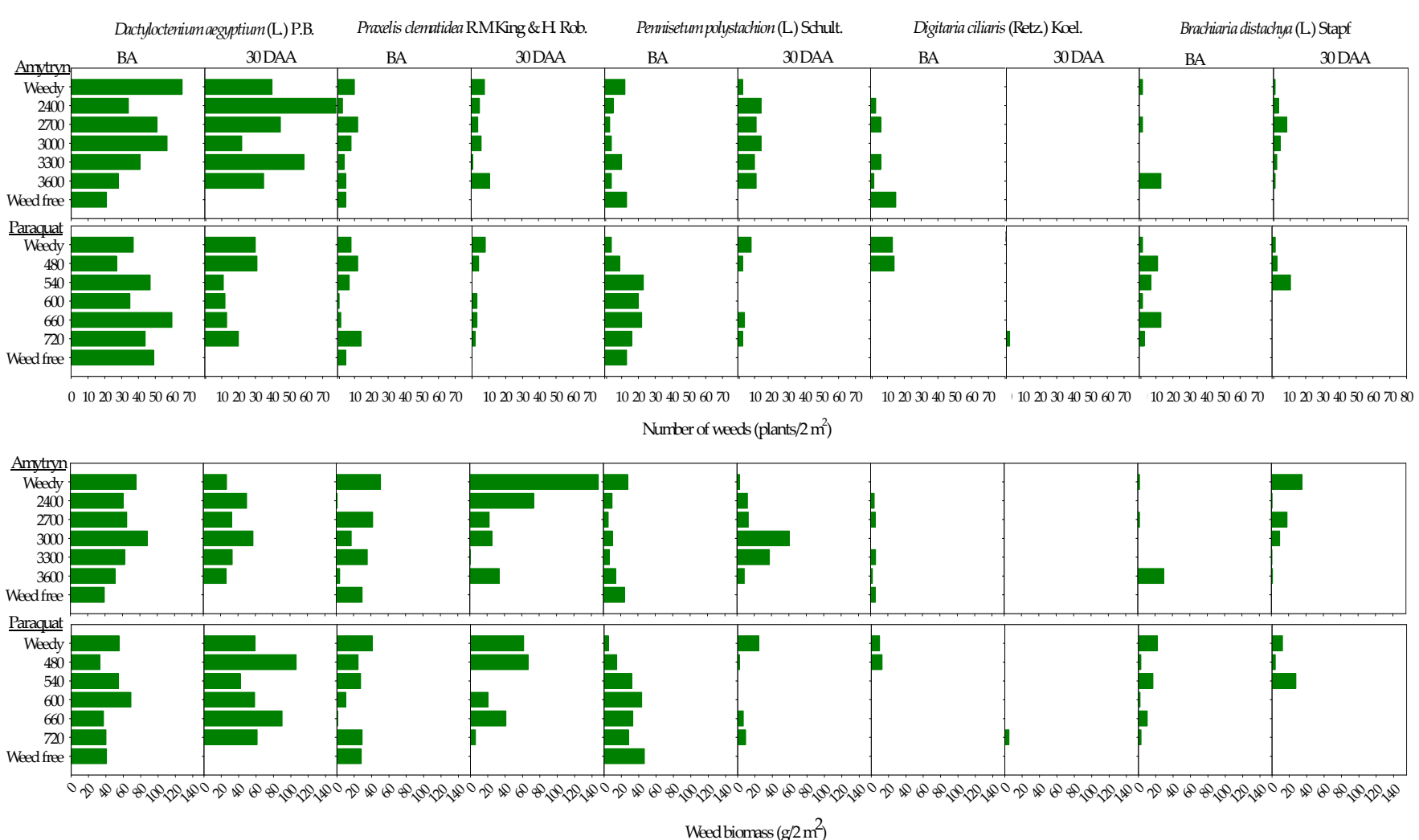

Figure 5. Effects of ametryn and paraquat applications on the number of weeds and biomass of the top-five weed species in Experiment I at before application (BA), and 30 days after application (DAA). The data measured from $2 \mathrm{~m}^{2}$, not statistically analyzed. The green bars represent number and biomass of individual weed species.

In Experiment II, twenty-six species of weeds were present in the field, consisting of 18 annual weed species $(69 \%)$ and eight perennial weed species $(31 \%)$. The morphological classification included 21 broad-leaved species $(81 \%)$ and five grass species (19\%) (Figures S3 and S4). The most dominant and detrimental species to sugarcane growth were B. distachya, D. aegyptium, P. Clematidea, Amaranthus viridis (L.), and Borreria laevis (Lmk.) Griseb weed species (Figure 6). Two species of weeds are problematic in the sugarcane fields of Northeast Thailand: B. distachya and D. aegyptium, with a relatively high number of weeds and weed biomass at BA (Figure 6). After the first application of each herbicide (tillering stage sugarcane), the number of weeds and biomasses of B. distachya and D. aegyptium decreased slightly at 30 DAA. Upon the second application of ametryn and paraquat on elongation stage of sugarcane, weed biomasses decreased, however, the number of weeds increased, particularly in B. distachya. Increases in number of weeds were attributed to weed re-growth or the development of new plantlets at the beginning of the rainy season (Figure 1). However, similar to the results found in Experiment I, the applications of both ametryn and paraquat did not decrease the number of weeds or weed biomass with increasing rates of herbicide (Figure 5). Two herbicide applications at the tillering and stalk elongation stages were found to decrease weed biomass, but did not affect number of weeds in some species, such as B. distachya in the ametryn application. Moreover, the paraquat herbicide application induced a re-growth of some weed species, such as B. distachya. The application of both herbicides at various rates produced relatively low effectiveness in controlling the most problematic weed species in both experiments. Therefore, the consideration of new methods for controlling such weeds species warrants future research. 


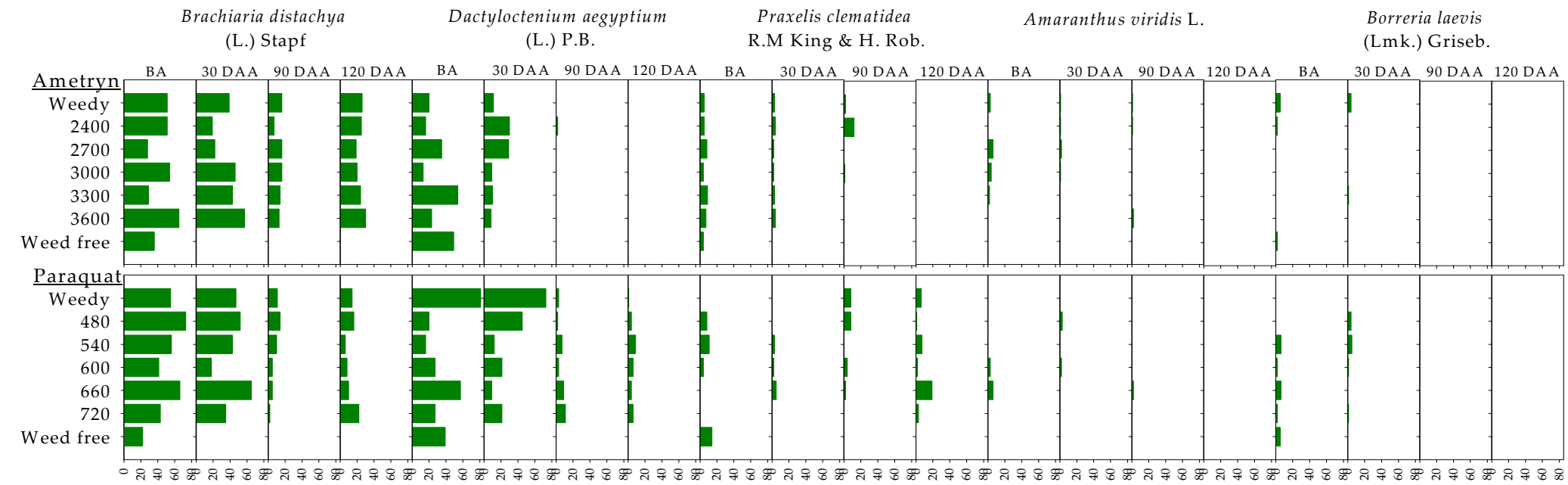

Number of weed (plants $/ 2 \mathrm{~m}^{2}$ )

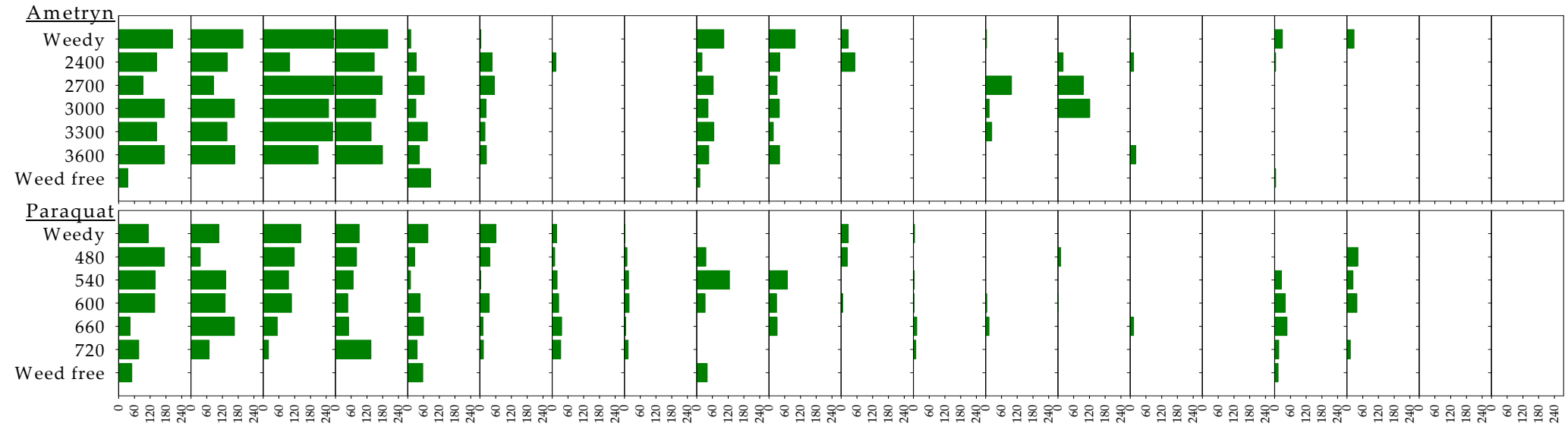

Weed biomass $\left(\mathrm{g} / 2 \mathrm{~m}^{2}\right)$

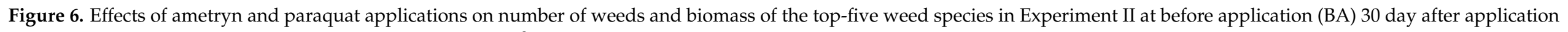
(DAA), 90 DAA, and 120 DAA. The data measured from $2 \mathrm{~m}^{2}$, not statistically analyzed. The green bars represent number and biomass of individual weed species. 
3.2. Effects of Post-Emergence Herbicides on Phytotoxicity of Herbicides on Sugarcane, Yield and Yield Components

3.2.1. Phytotoxicity and Recovery on Sugarcane in Experiment I and Experiment II

The applications of ametryn in both experiments resulted to less occurrence of phytotoxicity on sugarcane than that of the paraquat applications in every assessment period (Table 3). Experiment I showed that both herbicide applications, regardless of the rate, produced non-statistically different levels of toxicity in each assessment period (Table 3). In Experiment II, the toxicity was highly significant in both paraquat and ametryn treatments at all rates. In the first application of ametryn, phytotoxicity on sugarcane was recorded at rates of 2400 and $2700 \mathrm{~g}$ ai ha ${ }^{-1}$ was tend to less than 3000,3300 , and $3600 \mathrm{~g} \mathrm{ai} \mathrm{ha}^{-1}$ application at 3-30 DAA (Table 4). Upon the second application, the $3600 \mathrm{~g} \mathrm{ai} \mathrm{ha}^{-1} \mathrm{ame}^{-}$ tryn application produced the highest toxicity at 14-21 DAA. However, the first paraquat applications produced higher toxicity rates of 600,660 , and $720 \mathrm{~g}$ ai ha ${ }^{-1}$, which were not significantly different across each assessment period. The $720 \mathrm{~g}$ ai ha ${ }^{-1}$ paraquat application produced higher toxicity in both the first and second applications, showing a direct correlation with increased rates, which were immediately evident post-application (Table 4).

Table 3. Effects of ametryn and paraquat applications in various rates in Experiment I on phytotoxicity of herbicides on sugarcane and sugarcane recovery at $1,3,7,14,21$, and 30 DAA.

\begin{tabular}{|c|c|c|c|c|c|c|c|}
\hline \multirow{2}{*}{ Treatments } & \multicolumn{6}{|c|}{ Phytotoxicity of Herbicides on Sugarcane (\%) } & \multirow{2}{*}{ Sugarcane Recovery (Day) ${ }^{2}$} \\
\hline & $1 \mathrm{DAA}^{1 /}$ & 3 DAA & 7 DAA & 14 DAA & 21 DAA & 30 DAA & \\
\hline \multicolumn{8}{|c|}{ Ametryn (g ai ha $\left.{ }^{-1}\right)$} \\
\hline 2400 & 0.0 & 0.0 & 13.8 & 5.0 & 0.0 & 0.0 & 12 \\
\hline 2700 & 0.0 & 0.0 & 20.0 & 7.5 & 0.0 & 0.0 & 13 \\
\hline 3000 & 0.0 & 0.0 & 13.8 & 3.8 & 0.0 & 0.0 & 13 \\
\hline 3300 & 0.0 & 0.0 & 13.8 & 7.5 & 0.0 & 0.0 & 13 \\
\hline 3600 & 0.0 & 0.0 & 12.5 & 8.8 & 0.0 & 0.0 & 12 \\
\hline F-test & $\mathrm{ns}^{3 /}$ & ns & ns & ns & ns & ns & ns \\
\hline $\mathrm{CV} \%$ & 0.0 & 0.0 & 30.2 & 53.0 & 0.0 & 0.0 & 10.5 \\
\hline \multicolumn{8}{|c|}{ Paraquat (g ai ha ${ }^{-1}$ ) } \\
\hline 480 & 55.0 & 81.3 & 81.3 & 62.5 & 36.3 & 12.5 & 19 \\
\hline 540 & 53.8 & 88.8 & 88.8 & 63.8 & 37.5 & 16.3 & 19 \\
\hline 600 & 55.0 & 87.5 & 87.5 & 68.8 & 32.5 & 12.5 & 18 \\
\hline 660 & 60.0 & 83.8 & 83.8 & 65.0 & 33.8 & 12.5 & 18 \\
\hline 720 & 63.8 & 86.3 & 91.3 & 71.3 & 33.8 & 16.3 & 20 \\
\hline F-test & ns & ns & ns & ns & ns & ns & ns \\
\hline $\mathrm{CV} \%$ & 14.3 & 9.3 & 6.8 & 13.4 & 22.9 & 35.3 & 8.9 \\
\hline
\end{tabular}

For sugarcane recovery, the application of ametryn resulted in faster sugarcane recovery than the paraquat applications in both experiments (Tables 3 and 4). While the different rates of both herbicides in Experiment I produced non-statistically different results (Table 3), Experiment II produced the fastest sugarcane recovery speeds in the ametryn applications at the lower rates of 2400, and $2700 \mathrm{~g}$ ai ha ${ }^{-1}$ in tillering stage sugarcane (Table 4). The fastest sugarcane recoveries from paraquat in Experiment II were produced at the 480 and $540 \mathrm{~g}$ ai ha ${ }^{-1}$ rates in both the tillering and stalk elongation stages of sugarcane $(15,15$ to 18 , and 17 days, respectively). The results showed that high herbicide application rates required more time for sugarcane recovery. Moreover, high toxicity was related to the sugarcane's recovery (days). 


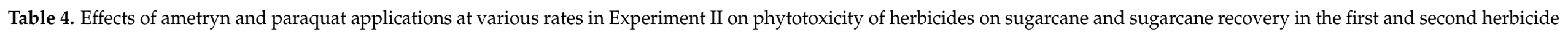
applications.

\begin{tabular}{|c|c|c|c|c|c|c|c|c|c|c|c|c|c|c|}
\hline \multirow{3}{*}{ Treatments } & \multicolumn{14}{|c|}{ Phytotoxicity of Herbicides on Sugarcane (\%) } \\
\hline & \multicolumn{6}{|c|}{ 1st Herbicides Application } & \multirow{2}{*}{$\begin{array}{l}\text { Sugarcane } \\
\text { Recovery } \\
\text { (Days) }^{2 /}\end{array}$} & \multicolumn{6}{|c|}{ 2nd Herbicides Application } & \multirow{2}{*}{$\begin{array}{c}\text { Sugarcane } \\
\text { Recovery } \\
\text { (Days) }\end{array}$} \\
\hline & ${\stackrel{1}{\text { DAA }^{1 /}}}^{1 /}$ & $\begin{array}{c}3 \\
\text { DAA }\end{array}$ & $\begin{array}{c}7 \\
\text { DAA }\end{array}$ & $\begin{array}{c}14 \\
\text { DAA }\end{array}$ & $\begin{array}{c}21 \\
\text { DAA }\end{array}$ & $\begin{array}{c}30 \\
\text { DAA }\end{array}$ & & $\begin{array}{c}1 \\
\text { DAA }\end{array}$ & $\begin{array}{c}3 \\
\text { DAA }\end{array}$ & $\begin{array}{c}7 \\
\text { DAA }\end{array}$ & $\begin{array}{c}14 \\
\text { DAA }\end{array}$ & $\begin{array}{c}21 \\
\text { DAA }\end{array}$ & $\begin{array}{c}30 \\
\text { DAA }\end{array}$ & \\
\hline \multicolumn{15}{|c|}{ Ametryn (g ai ha $\left.{ }^{-1}\right)$} \\
\hline 2400 & 0.0 & $13.8 c^{3 /}$ & $16.3 \mathrm{c}$ & $20.0 \mathrm{~b}$ & $14.5 \mathrm{c}$ & $7.5 \mathrm{c}$ & $15 \mathrm{bc}$ & 0.0 & 0.0 & $12.5 \mathrm{~b}$ & 12.5 & $0.0 \mathrm{~b}$ & 0.0 & 14 \\
\hline 2700 & 0.0 & $16.3 \mathrm{bc}$ & $18.8 \mathrm{bc}$ & $20.0 \mathrm{~b}$ & $15.8 \mathrm{c}$ & $9.8 \mathrm{bc}$ & $13 \mathrm{c}$ & 0.0 & 0.0 & $10.0 \mathrm{~b}$ & 15.0 & $8.8 \mathrm{a}$ & 0.0 & 16 \\
\hline 3000 & 0.0 & $26.3 \mathrm{a}$ & $31.3 \mathrm{a}$ & $35.0 \mathrm{a}$ & $20.5 \mathrm{bc}$ & $13.3 \mathrm{ab}$ & $16 \mathrm{ab}$ & 0.0 & 0.0 & $16.8 \mathrm{~b}$ & 12.5 & $7.5 \mathrm{a}$ & 0.0 & 14 \\
\hline 3600 & 0.0 & $23.8 \mathrm{ab}$ & $25.0 \mathrm{ab}$ & $35.0 \mathrm{a}$ & $30.3 \mathrm{a}$ & $16.8 \mathrm{a}$ & $18 \mathrm{a}$ & 0.0 & 0.0 & $26.3 \mathrm{a}$ & 22.5 & $11.3 \mathrm{a}$ & 0.0 & 17 \\
\hline F-test & $\mathrm{ns}^{4 /}$ & $* 5 /$ & $* * 6 /$ & ** & $* *$ & * & $* *$ & ns & ns & $* *$ & ns & $* *$ & ns & ns \\
\hline $\mathrm{CV} \%$ & 0.0 & 26.4 & 19.9 & 13.8 & 22.7 & 29.2 & 9.1 & 0.0 & 0.0 & 32.5 & 36.4 & 35.1 & 0.0 & 12.1 \\
\hline \multicolumn{15}{|c|}{ Paraquat (g ai ha ${ }^{-1}$ ) } \\
\hline 480 & $75.0 \mathrm{~b}$ & $80.8 \mathrm{~b}$ & $61.3 \mathrm{~b}$ & $54.5 \mathrm{~b}$ & $30.0 \mathrm{c}$ & $15.3 \mathrm{c}$ & $15 b$ & $65.0 \mathrm{a}$ & 64.3 & $70.0 \mathrm{c}$ & 58.8 & $35.0 \mathrm{~b}$ & $17.5 \mathrm{~b}$ & $18 \mathrm{bc}$ \\
\hline 540 & $57.5 \mathrm{c}$ & $63.8 \mathrm{c}$ & $77.5 \mathrm{a}$ & $60.0 \mathrm{~b}$ & $37.5 \mathrm{~b}$ & $16.3 \mathrm{bc}$ & $15 \mathrm{~b}$ & $65.0 \mathrm{a}$ & 72.5 & $73.8 \mathrm{bc}$ & 52.5 & $28.8 \mathrm{~b}$ & $10.0 \mathrm{c}$ & $17 \mathrm{c}$ \\
\hline 600 & $82.5 \mathrm{ab}$ & $87.5 \mathrm{ab}$ & $85.0 \mathrm{a}$ & $72.5 \mathrm{a}$ & $39.5 \mathrm{ab}$ & $19.3 \mathrm{ab}$ & $19 \mathrm{a}$ & $50.0 \mathrm{~b}$ & 67.5 & $76.3 \mathrm{a}-\mathrm{c}$ & 61.8 & $38.3 \mathrm{~b}$ & $14.3 \mathrm{bc}$ & $20 \mathrm{ab}$ \\
\hline 660 & $88.8 \mathrm{a}$ & $90.0 \mathrm{ab}$ & $87.5 \mathrm{a}$ & $75.0 \mathrm{a}$ & $41.3 \mathrm{ab}$ & $19.5 \mathrm{ab}$ & $19 \mathrm{a}$ & $67.5 \mathrm{a}$ & 70.0 & $81.3 \mathrm{ab}$ & 62.5 & $40.0 \mathrm{ab}$ & $17.5 \mathrm{~b}$ & $20 a b$ \\
\hline F-test & $* *$ & $* *$ & $* *$ & $* *$ & $* *$ & * & $* *$ & * & ns & * & ns & * & ** & * \\
\hline $\mathrm{CV} \%$ & 10.8 & 10.0 & 11.0 & 11.1 & 10.4 & 12.3 & 10.6 & 12.0 & 17.3 & 6.6 & 10.5 & 19.7 & 23.8 & 9.6 \\
\hline
\end{tabular}

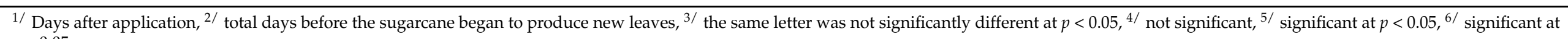
$p<0.05$. 


\subsubsection{Herbicide Application Effects to Yield and Yield Components of Sugarcane}

In Experiment I, the ametryn applications at various rates were not significantly different in sugarcane yield and yield components (Table 5). The application of paraquat at the rate of $480 \mathrm{~g} \mathrm{ai} \mathrm{ha}^{-1}$ resulted in cane stand (56,713 stalk ha ${ }^{-1}$ ) and cane yield (91.0 ton ha ${ }^{-1}$ ) similar to that of a weed-free treatment and greater yield and yield component. In Experiment II, the ametryn applications at various rates resulted in significant differences in cane stand and cane yield. The ametryn application at the rate of 2700, 3000, 3300, and $3600 \mathrm{~g}$ ai ha ${ }^{-1}$ resulted in a similar cane yield (88.3-89.4 ton ha ${ }^{-1}$ ). The paraquat application at the rate of $600 \mathrm{~g} \mathrm{ai} \mathrm{ha} \mathrm{ha}^{-1}$ resulted in increased cane stand $\left(70,486 \mathrm{stalk} \mathrm{ha}^{-1}\right)$ and greater cane yield (94.6 ton ha ${ }^{-1}$ ) than other rates. However, the herbicide applications at various rates in both experiments did not affect commercial cane sugar percentages (CCS) (Table 5). The result indicated that paraquat application was affected to cane yield, even though in one or two applications, low rate of application was the lowest effect to cane yield. On the other hand, ametryn did not affect cane yield for one time at the tillering stage of sugarcane. However, two-time applications had a higher effect on cane yield than one-time application. For ametryn, two-time application was a greater choice for weed control, and not significant in cane yield. Paraquat had high phytotoxicity on sugarcane and cane yield, but at the recommended rate $\left(600 \mathrm{~g}\right.$ ai ha $\left.{ }^{-1}\right)$ was the great choice for weed control and cane yield.

Table 5. Effects of ametryn and paraquat applications at various rates on yield and yield components of sugarcane in Experiments I and II.

\begin{tabular}{|c|c|c|c|c|c|c|}
\hline \multirow[b]{2}{*}{ Treatments } & \multicolumn{3}{|c|}{ Experiment I } & \multicolumn{3}{|c|}{ Experiment II } \\
\hline & $\begin{array}{l}\text { Cane Stand } \\
\text { (stalk ha-1) }\end{array}$ & $\begin{array}{l}\text { Cane Yield } \\
\left(\text { ton ha } \mathrm{h}^{-1}\right)\end{array}$ & $\begin{array}{l}\text { C.C.S. } \\
\text { (ccs) }\end{array}$ & $\begin{array}{l}\text { Cane Stand } \\
\left(\text { stalk ha }{ }^{-1} \text { ) }\right.\end{array}$ & $\begin{array}{l}\text { Cane Yield } \\
\text { (ton ha }^{-1} \text { ) }\end{array}$ & $\begin{array}{l}\text { C.C.S. } \\
\text { (ccs) }\end{array}$ \\
\hline \multicolumn{7}{|l|}{ Ametryn (g ai ha ${ }^{-1}$ ) } \\
\hline Weedy & 62,421 & 95.3 & 14.1 & $60,185 b^{1 /}$ & $29.7 \mathrm{c}$ & 16.7 \\
\hline 2400 & 73,611 & 101.5 & 15.7 & $54,630 \mathrm{~b}$ & $55.7 \mathrm{~b}$ & 16.9 \\
\hline 2700 & 79,630 & 113.1 & 15.2 & $63,194 \mathrm{~b}$ & $88.3 \mathrm{a}$ & 17.8 \\
\hline 3000 & 80,273 & 119.6 & 16.2 & $54,782 \mathrm{~b}$ & $80.1 \mathrm{a}$ & 17.3 \\
\hline 3300 & 84,491 & 128.8 & 15.6 & $64,943 \mathrm{~b}$ & $88.8 \mathrm{a}$ & 16.9 \\
\hline 3600 & 72,068 & 123.8 & 15.2 & $60,185 \mathrm{~b}$ & $89.4 \mathrm{a}$ & 17.6 \\
\hline Weed-free & 88,194 & 134.5 & 14.7 & $78,472 \mathrm{a}$ & $90.8 \mathrm{a}$ & 16.1 \\
\hline F-test & $\mathrm{ns}^{2 /}$ & ns & ns & $* 3 /$ & $* * 4 /$ & ns \\
\hline $\mathrm{CV} \%$ & 13.5 & 16.3 & 11.1 & 13.1 & 13.1 & 4.9 \\
\hline \multicolumn{7}{|l|}{ Paraquat (g ai ha ${ }^{-1}$ ) } \\
\hline Weedy & $44,745 \mathrm{bc}$ & $56.6 \mathrm{bc}$ & 16.0 & $37,500 \mathrm{c}$ & $62.9 \mathrm{c}$ & 16.5 \\
\hline 480 & $56,713 \mathrm{ab}$ & $91.0 \mathrm{ab}$ & 15.7 & $40,104 \mathrm{c}$ & $65.0 \mathrm{c}$ & 15.8 \\
\hline 540 & $57,043 \mathrm{ab}$ & $69.4 \mathrm{~b}$ & 16.2 & $55,057 \mathrm{~b}$ & $63.0 \mathrm{c}$ & 16.4 \\
\hline 600 & $47,454 \mathrm{bc}$ & $69.0 \mathrm{~b}$ & 16.5 & 70,486 a & $94.6 \mathrm{~b}$ & 16.6 \\
\hline 660 & 43,772 bc & $54.9 \mathrm{bc}$ & 16.0 & $32,292 \mathrm{c}$ & $22.1 \mathrm{~d}$ & 16.8 \\
\hline 720 & $25,301 \mathrm{c}$ & $31.2 \mathrm{c}$ & 16.4 & $32,407 \mathrm{c}$ & $26.6 \mathrm{~d}$ & 17.3 \\
\hline Weed-free & 79,398 a & $117.1 \mathrm{a}$ & 15.9 & 82,292 a & $113.8 \mathrm{a}$ & 16.9 \\
\hline F-test & * & $* *$ & $\mathrm{~ns}$ & $* *$ & $* *$ & $\mathrm{~ns}$ \\
\hline $\mathrm{CV} \%$ & 32.4 & 24.8 & 5.7 & 16.2 & 14.0 & 5.0 \\
\hline
\end{tabular}

${ }^{1 /}$ Means in the same column with the same letter are not significantly different at $p<0.05,{ }^{2 /}$ not significant, ${ }^{3 /}$ significant at $p<0.05$, and

4/ significant at $p<0.01$.

\section{Discussion}

Our study found that the application of paraquat resulted in relatively greater weed control (Figures 2 and 3), but higher phytotoxicity on sugarcane (Tables 3 and 4) than the ametryn applications at every assessment period. Consistent with a study of itchgrass [Rottboellia cochinchinensis (L.) Clayton], Lencse [34] found paraquat to be more effective than ametryn. Paraquat is classified as a contact herbicide and is not translocated extensively 
throughout the plant. It acts quickly with no selectively, and is lethal to all plant cells it comes in contact with. Ametryn is a pre- and post-emergence, slowly acting herbicide, that moves within the plant's structure $[19,20]$. The superior performance of paraquat was evidenced in both weed control and weed biomass (Figures 2 and 3). Senseman [21] reported that ametryn's effectiveness was due to an $\mathrm{LD}_{50}$ value of $1160 \mathrm{mg} \mathrm{kg}^{-1}$, whereas paraquat presented an $\mathrm{LD}_{50}$ value of 112 to $150 \mathrm{mg} \mathrm{kg}^{-1}$; indicating paraquat's significantly higher toxicological properties. The durability of some herbicides may deteriorate within a few days, while others may remain effective for months or even years [35]. Ametryn decomposition in aerobic soil has been shown to have a half-life at 10 to 38 days [26,36], whereas the half-life of paraquat occurred at approximately 20 years [37,38].

The above factors suggest the varied effects of different herbicides in weed control, phytotoxicity, and subsequent weed recovery. Slower weed recovery increases the weedfree period, which aids in the growth and subsequent yield of sugarcane [39]. However, the experiments herein determined that both herbicides at various rates resulted in similar levels of weed control, due to the age and canopy size of the weeds; thereby acknowledging the need for reduced herbicide application rates at the correct time. The large size of the weeds canopy in our experiment, similar to those of most commercial sugarcane fields, suggests that paraquat would be the better choice. However, weeds with several large leaves reduce the herbicide's effectiveness, as noted by Heri et al. [19]. Gebreegziabher et al. [39] further reported that the critical period of weed competition in sugarcane grown in Ethiopian fields was between 16 and 126 DAP, which created a lower and acceptable yield of $5 \%$. While the aforementioned herbicides are best suited for controlling weeds in sugarcane fields, the application rates and timing, as well as phytotoxicity on sugarcane and yield components, must also be taken into account [40].

In Experiment I, the effectiveness of both herbicides in controlling weed density and weed biomass showed gradual declines and disappeared within 30 to 60 DAA. Increases in weed biomass at 90 DAA were attributed to the successful growth of some weed species up to the reproductive stage, which completes the life cycle, particularly within a single herbicide application (Figure 4b). As expected, the two applications utilized in Experiment II better controlled the re-growth of weeds (Figure 4d). Moreover, both experiments found that the dominant weed species were able to germinate, reach maturity, and successfully compete with other weed species. Shade-tolerance was another characteristic characterized by the most common weed species in sugarcane fields. The major weed species in Experiment I were D. aegyptium, P. Clematidea, and P. polystachion, where B. distachya and D. aegyptium were predominant in Experiment II. Dominant weed species vary from region to region and from site to site. For example, in the Southern Guinea savanna of Nigeria, the I. cylindrica, torpedo grass (Panicum repens L.), R. cochinchinensis, and two sedge weeds, sierra leone (Mariscus longibracteatus Cherm) and purple nutsedge (Cyperus rotundus L.), are abundant [41]. In the Cuddalore district of Tamil Nadu, India, the horse purslane (Trianthema portulacastrum L.) and C. rotundus are dominant [42]. In Thailand, weed species such as D. aegyptium, E. indica, P. polystachion, C. rotundus, and jungle rice (Echinochloa colona (L.) Link) are dominant. The methods used to control the dominant weed species are, therefore, dependent on species, environment, and soil type [16]; as well as the dissipation of toxicity at 30 to 60 DAA (Figure 2).

Weed species and habitat are the major criteria required for weed management in the field. D. aegyptium is an annual or short-perennial grass, up to $75 \mathrm{~cm}$ in height, with slender, well-branched stems. Its roots are horizontal and spread primarily by seeds that creep from the lower nodes [43-45], making it effective in competing with other species. Its droughttolerant grass grows rapidly in Thailand's wet season [13], allowing the species to reach peak weed biomass at 30 to 90 DAA, particularly in the rainy season of Thailand (Figure 1). Additionally, a dominant weed species in Tamil Nadu, India, D. aegyptium, removes significant water and nutrients from the soil causing heavy losses to sugarcane yields [46]. Soil preparation, including stale seedbed, ploughing, propanil application, and hand weeding were methods often used to control this evasive weed in upland rice fields [47]. 
Intercropping of green gram, cowpeas, soybeans, and groundnuts in sorghum suppressed the growth of D. aegyptium grass and increased sorghum yields [48]. Chauhan [49] reported that $D$. aegyptium was effectively controlled through soil inversion (tillage), which buries weed seeds at a depth of $6 \mathrm{~cm}$ or greater, and using crop residue as mulch. Notably, the post-emergence herbicides, such as fenoxaprop-p-ethyl + ethoxysulfuron at $45 \mathrm{~g}$ ai ha $\mathrm{ha}^{-1}$ was applied at the four- to six-leaf stage.

P. Clematidea, classified as an annual or short-lived perennial, 100 to $130 \mathrm{~cm}$ in height, which causes significant agricultural destruction in rubber plantations, orchards, and other economic crops across Asia and Australia, including Thailand's sugarcane production [50,51]. Khamare et al. [52] reported that the application of flumioxazin consistently provided over $90 \%$ control of $P$. Clematidea. Further use of glyphosate, triclopyr, and clopyralid to mature and flowering weeds resulted in the control of these dominant species; however, the use of pre- and post-emergence herbicides in sequential applications may be needed for long-term management.

P. polystachion, also an annual or perennial herb, has branched culms geniculately ascending into 30 to $200 \mathrm{~cm}$ long lateral branches [53]. Germination of this species can be prevented up to the first five weeks of growth by selecting the correct planting time, hand weeding to remove seedlings, cutting before the flowering stage, and the use of pre-emergence herbicides; such as trifluralin, atrazine, nitralin, and bromacil. Beyond that time, when growth reaches 20 to $25 \mathrm{~cm}$, the use of prometryne, linuron, diuron, and glyphosate are more appropriate for weed control [54].

$B$. distachya displays competitive growth characteristics; stoloniferous, widely spreading and slender with culms, creeping on the surface of the soil, branched, and rooting at the lower nodes. At one to two meters in length, this weed spreads readily via stolons that are cut, sprout, and take root $[45,55]$. Its growth characteristics, including shade tolerance, allow this species to successfully compete with other species, evident herein, in both sugarcane and coconut plantations [56]. B. distachya, as well as D. aegyptium and bermuda grass (Cynodon dactylon (L.) Pers.), are capable of hosting phytoplasma bacteria and pathogens responsible for white-leaf disease in sugarcane [57], which are also capable of re-infecting sugarcane [58-60].

In an overview, $B$. distachya and $D$. aegyptium were the most damaging to sugarcane yields. Both weed densities and biomasses decreased with time, whereas the infestation of $B$. distachya remained relatively stable, minimally affected by either herbicide. Galinato et al. [55] determined that control of $B$. distachya was best achieved at the one- to three-leaf stage by early-post-emergence application of fenoxaprop-p-ethyl ( $\left.34 \mathrm{~g} \mathrm{ha}^{-1}\right)$, and with higher rates at the four-leaf tiller ${ }^{-1}\left(45 \mathrm{~g} \mathrm{ha}^{-1}\right)$ and two to four tiller $\left(56 \mathrm{~g} \mathrm{ha}^{-1}\right)$ stages Notably, the rate of herbicide increases with the age of the weeds. Manidool [61] reported that $B$. distachya proved tolerant of poor soil, but cannot withstand waterlogging; indicating that flooding may also be another way to control the species. Weed management in the harvesting of sugarcane also involves weeding methods, which must be examined before the selection of herbicides.

Regarding phytotoxicity on sugarcane, both herbicides showed the highest toxicity rates at 7 DAA and decreased to their minimum levels at 30 DAA (Tables 3 and 4), similar to the weed control trend (Figure 2). Pavani et al. [29] reported that the chlorophyll content and potential quantum efficiency of photosystem II (Fv/Fm) in sugarcane leaves after 40 days of paraquat application were not affected, and the phytotoxicity on sugarcane was reduced to the minimum, compared with 1 and 2 DAA. Paraquat produced higher toxicity in sugarcane compared with the slower recovery of ametryn. Santos et al. [62] found that the recovery of sugarcane plants depends primarily on the type of phytotoxicity symptoms, toxicity intensity, and the climate conditions after their occurrence. Both herbicide applications showed higher phytotoxicity on sugarcane and slower sugarcane recovery in tillering stage cane versus stalk elongation stage, demonstrating that herbicide tolerance in sugarcane depends on its variety, age, and the phenological developmental stage of the sugarcane at the time of application [63,64]. Richardson [23] reported that 
sugarcane growth stages at the time of herbicide application $(2,4-\mathrm{D})$ and the method of application both play important roles in determining the degree of phytotoxicity within the cane. Within our study, the application of both herbicides at various rates resulted in non-significantly different levels of phytotoxicity on sugarcane; however, increased herbicide rates resulted in a linear increase in toxicity. Notably, the dual applications at tillering and stalk elongation stage of sugarcane in Experiment II were unable to control $B$. distachya (Figure 6), and created a re-toxicity, as well as interrupted growth. The reduction in the rates and times of the herbicide applications resulted in the disruption of sugarcane growth and reducing production costs to farmers. Zhang et al. [65] further determined that these factors play an important role in eliminating the detrimental environmental side-effects and assist in reducing the weeds' resistance to herbicides.

The results of Experiment I determined that ametryn applications at various rates resulted in non-significantly different sugarcane yield compositions, due to the relatively low toxicity produced by the herbicide (Table 3); whereas the paraquat application at various rates resulted in decreased sugarcane yield and yield components commensurate with increased application rates. Pavani et al. [29] reported a negative correlation in the amount of paraquat with the fresh biomass of sugarcane, in which increased amounts of herbicide resulted in decreased cane stand and cane yield. Experiment II demonstrated that lower application rates of ametryn resulted in low cane yields, while cane stand did not differ between rates. Through various application rates of paraquat, we determined that the recommended rate $\left(600 \mathrm{~g}\right.$ ai ha $\left.{ }^{-1}\right)$ resulted in higher cane stands and cane yields. However, in both experiments, the applications of both herbicides at various rates resulted in non-significantly different commercial cane sugar percentages.

\section{Conclusions}

We may conclude through our experiments that the optimal applications of ametryn and paraquat can be applied only once for the tillering stage of sugarcane at rates of

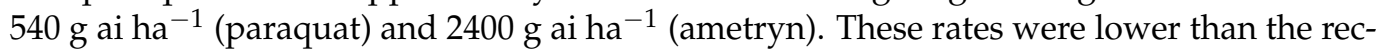
ommended rates, which represented the minimum amounts necessary to control Thailand's dominant weed species; D. aegyptium, P. clematidea, P. polystachion, and B. distachya.

Supplementary Materials: The following are available online at https: / www.mdpi.com/2073-4 395/11/3/429/s1, Figure S1: Effects of ametryn applications on the number of weed (green bar) and weed biomass (red bar) of total weed species in Experiment I at before application (BA), 30, 60, 90, 120, and 150 days after application (DAA), Figure S2: Effects of paraquat applications on the number of weed (green bar) and weed biomass (red bar) of total weed species in Experiment I at before application (BA), 30, 60, 90, 120, and 150 days after application (DAA), Figure S3: Effects of ametryn applications on the number of weed (green bar) and weed biomass (red bar) of total weed species in Experiment II at before 1st application (BA), 30, 60, 90 (before 2nd application), 120, and 150 days after application (DAA), Figure S4: Effects of paraquat applications on the weed density and biomass of total weed species in Experiment II at before 1st application (BA), 30, 60, 90 (before 2nd application), 120, and 150 days after application (DAA).

Author Contributions: Conceptualization, S.G., and P.A.; methodology, P.A.; software, P.A.; validation, P.A., S.G., P.S. and N.J.; formal analysis, P.A.; investigation, S.G.; resources, S.G.; data curation, P.A.; writing—original draft preparation, P.A.; writing—review and editing, S.G.; visualization, S.G.; supervision, S.G.; project administration, S.G.; funding acquisition, S.G. All authors have read and agreed to the published version of the manuscript.

Funding: This research was funded by the government of Thailand's grants to Khon Kaen University (KKU) (FY2017: 601902 and FY2018: 61003903) through the Research Scholar Project of Santimaitree Gonkhamdee.

Acknowledgments: We would like to express our gratitude to The Northeast Thailand Cane and Sugar Research Center, Faculty of Agriculture, Khon Kaen University, Khon Kaen, Thailand. Lastly, we would like to thank Sompong Chankaew and Tidarat Monkham for proofing the manuscript.

Conflicts of Interest: No conflicts of interest are declared. 


\section{References}

1. Mehra, S.P.; Kanwar, R.S.; Brar, L.S. Weed management in spring-planted sugarcane. J. Res. Punjab. Agric. Univ. 1990, $27,401-407$.

2. Zafar, M.; Tanveer, A.S.I.F.; Cheema, Z.A.; Ashraf, M. Weed-crop competition effects on growth and yield of sugarcane planted using two methods. Pak. J. Bot 2010, 42, 815-823.

3. Yirefu, F.; Tana, T.; Tafesse, A.; Zekarias, Y. Weed interference in the sugarcane (Saccharum officinarum L.) plantations of Ethiopia. Agric. For. Fish. 2013, 2, 239-247. [CrossRef]

4. Farooq, M.A.; Haider, K.; Ahmad, S.; Zubair, M.; Afghan, S. Efficacy of different post-emergence chemical application for summer weeds management in sugarcane. Pak. Sugar J. 2014, 29, 16.

5. Zimdhal, R.L. Weed Crop Competition: A Review; International Plant Protection Centre, Oregon state University: Corvallis, OR, USA, 1980; pp. 68-69.

6. Suwanarak, K. Weed management in sugarcane in Thailand. Weed Manag. IN Sugarcane Thail. 1990, 38, $199-214$.

7. Marshall, E.J.P.; Brown, V.K.; Boatman, N.D.; Lutman, P.J.W.; Squire, G.R.; Ward, L.K. The role of weeds in supporting biological diversity within crop fields. Weed Res. 2003, 43, 77-89. [CrossRef]

8. Pinke, G.; Pál, R.; Botta-Dukát, Z. Effects of environmental factors on weed species composition of cereal and stubble fields in western Hungary. Open Life Sci. 2010, 5, 283-292. [CrossRef]

9. Nagy, K.; Lengyel, A.; Kovács, A.; Türei, D.; Csergő, A.M.; Pinke, G. Weed species composition of small-scale farmlands bears a strong crop-related and environmental signature. Weed Res. 2018, 58, 46-56. [CrossRef]

10. Food and Agriculture Organization of the United Nations FAO. Crops and Livestock Products. Available online: http://www. fao.org/faostat/en/\#data/QC (accessed on 7 February 2020).

11. Tippayawat, A.; Ponragdee, W.; Sansayawichai, T. Characteristics of Thai sugarcane (Saccharum spp. hybrids) cultivars and potential for utilization. Khon Kaen Agric. J. 2012, 40, 53-59.

12. Manivong, P.; Bourgois, E. White Paper: Thai Sugarcane Sector and Sustainability. 2017. Available online: https://www.bonsucro. com/wp-content/uploads/2017/08/Thai-White-Paper-FINAL-LowRes.docx.pdf (accessed on 17 August 2020).

13. Heuzé, V.; Tran, G.; Maxin, G.; Lebas, F. Egyptian Crowfoot Grass (Dactyloctenium aegyptium). Feedipedia, A Programme by INRA, CIRAD, AFZ and FAO. 2015. Available online: https:/ / www.feedipedia.org/node/465 (accessed on 3 January 2020).

14. Skerman, P.J.; Riveros, F. Tropical Grasses; FAO Plant Production and Protection Series No. 23; FAO and UN: Rome, Italy, 1990; pp. 323-327.

15. Huang, H.; Guo, S.; Chen, G. Reproductive biology in an invasive plant Solidago canadensis. Front. Biol. China 2007, 2, 196-204. [CrossRef]

16. Suwanarak, K. Weed in sugarcane Fields. Thai Agric. Res, J. 1994, 12, 222.

17. KALRO-Sugar Research Institute. Sugarcane Weed Management in Kenya's Sugar Industry; Sugarcane Breeding Centre-Mtwapa of Bamburi: Bamburi, Kenya, 2015; pp. 7-14.

18. Sutthiwaree, P.; Sananarong, A.; Khaehanchanpong, Y.; Chamsing, A.; Wannarong, K.; Sangpanta, P.; Veeriyanon, S.; Pamart, K.; Arawin, N. Research and development of spring tine attached to small Tractor for sugarcane weeder. Thai Agric. Res. J. 2010, 28, 157-169.

19. Heri, W.; Pfister, F.; Carroll, B.; Parshley, T.; Nabors, J.B. Production, development, and registration of triazine herbicides. In The Triazines Herbicides; Agricultural Chemistry Consultant: Greensboro, NC, USA, 2008; pp. 31-43. [CrossRef]

20. Heggen, R.J. Floating Islands: An Activity Book. 2015. Available online: https://archive.org/details/FloatingIslands/page/n865 / mode/2up (accessed on 15 June 2020).

21. Senseman, S.A. Herbicide Handbook, 9th ed.; Weed Science Society of America: Lawrence, KS, USA, 2007 ; pp. 126-188.

22. Chagas, R.M.; Silveira, J.A.; Ribeiro, R.V.; Vitorello, V.A.; Carrer, H. Photochemical damage and comparative performance of superoxide dismutase and ascorbate peroxidase in sugarcane leaves exposed to paraquat-induced oxidative stress. Pestic. Biochem. Physiol. 2008, 90, 181-188. [CrossRef]

23. Richardson, E. Critical growth stages for 2, 4-D phytotoxicity to sugarcane in South Africa. In Proceedings of the South African Sugar Technologists' Association, Durban, South Africa, 17-21 June 1972; Volume 6, pp. 168-175.

24. Azania, C.A.M.; Pinto, L.R.; Adriano, R.C.; Perecin, D.; Azania, A.P. The Use of Glyphosate in Sugarcane: A Brazilian Experience. Herbic. Curr. Res. Case Stud. Use 2013, 153-173. [CrossRef]

25. Ghanbarpour, N.; Zand, E.; Sajedi, N. Efficacy of post-emergence herbicide for managing Diplachne fusca in sugarcane field. Aust. J. Basic Appl. Sci. 2015, 3, 108-117.

26. Takim, F.O.; Suleiman, M.A.; Omotosho, S.B. Efficacy of ametryn herbicides on weeds in rainfed and irrigated sugarcane fields in southern guinea savanna ecology of Nigeria. Pak. J. Weed Sci. Res. 2016, 22, 353-363.

27. da Silva, A.F.; Galon, L.; Concenço, G.; Aspiazú, I.; Ferreira, E.A.; Tironi, S.P.; da Silva, A.A. Sugarcane cultivars present differential susceptibility to herbicides ametryn and trifloxysulfuron-sodium. Aust. J. Crop Sci. 2014, 8, 965-972.

28. Simões, P.S.; Carbonari, C.A.; Nascentes, R.F.; Stasievski, A.; Velini, E.D. Selectivity of herbicides inhibitors of photosystem II for sugarcane cultivars. Planta Daninha 2016, 34, 803-814. [CrossRef]

29. Pavani, A.A.; Guimarães, A.C.R.; Brunharo, C.A.D.C.G.; Christoffoleti, P.J. Physiological characterization of sugarcane varieties under oxidative stress caused by the herbicide paraquat. Cientifica 2015, 43, 43-49. [CrossRef] 
30. Forestry and Fisheries. Sugarcane Production Guideline. Department of Agriculture, Forestry and Fisheries. 2014. Available online: https:/ / www.dalrrd.gov.za/Portals/0/Brochures\%20and\%20Production\%20guidelines/sugar\%20cane\%20prodocution\%20 \%20guideline.pdf (accessed on 10 January 2020).

31. Frans, R.E.; Talbert, R.E. Design of Field Experiments and the Measurement and [statistical] Analysis of Plant Responses. In Research Methods in Weed Science; Southern Weed Science Society; Truelove, B., Ed.; Auburn University: Auburn, AL, USA, 1977; pp. 15-23.

32. Noda, K.; Teerawatsakul, M.; Prakongvongs, C.; Chaiwiratnukul, L. Major Weed in Thailand; MASS \& MEDIAS Co., LTD.: Bangkok, Thailand, 1994; pp. 1-164.

33. Albertson, P.L.; Grof, C.P. The effect of hexose upon Pol, Brix and calculated CCS in sugarcane: A potential for negative Pol bias in juice from actively growing cane. J. Am. Soc. Sugar Cane Technol. 2014, 24, 185-198.

34. Lencse, R.J. Itch Grass Interference and Control in Sugarcane in Louisiana. Ph.D. Thesis, Louisiana State University and Agricultural and Mechanical College, Louisiana, LA, USA, 1990.

35. da Silva, A.A.; de Oliveira Junior, R.S.; da Costa, E.R.; Ferreira, L.R.; Constantin, J.; Apoloni, D.K.M.; de Oliveira, M.F. Persistência de herbicidas do grupo das imidazolinonas e efeitos sobre as culturas sucessoras de milho e sorgo. Acta Sci. Agron. 1999, 21, 459-465. [CrossRef]

36. USEPA. Reregistration Eligibility Decision (RED) for ametryn. The United States Environmental Protection Agency, EPA 738-R05-006. Available online: https:/ / archive.epa.gov/pesticides/reregistration/web/pdf/ametryn_red.pdf (accessed on 20 June 2019).

37. Konthonbut, P.; Kongtip, P.; Nankongnab, N.; Tipayamongkholgul, M.; Yoosook, W.; Woskie, S. Paraquat exposure of pregnant women and neonates in agricultural areas in Thailand. Int. J. Environ. Res. Public Health. 2018, 15, 1163. [CrossRef]

38. Watts, M. Paraquat. Available online: http:/ / wssroc.agron.ntu.edu.tw/note/Paraquat.pdf (accessed on 10 June 2020).

39. Gebreegziabher, W.; Ram, S.V.; Samuel, T. Assessment of Critical Period of Weed Competition in Sugarcane (Saccharum spp. Hybrid) at Tana Beles Sugar Development Project, Ethiopia. Int. J. Adv. Res. Biol. Sci. 2018, 5, 91-99. [CrossRef]

40. Nurse, R.E.; Hamill, A.S.; Swanton, C.J.; Tardif, F.J.; Sikkema, P.H. Weed control and yield response to foramsulfuron in corn. Weed Technol. 2007, 21, 453-458. [CrossRef]

41. Takim, F.O.; Amodu, A. Quantitative estimate of weeds of sugarcane (Saccharum officinarum L.) crop in Ilorin, Southern Guinea Savanna of Nigeria. Ethiop J. Environ. Stud. Manag. 2013, 6, 611-619. [CrossRef]

42. Murugan, G.; Kathiresan, R. Ecological studies on weeds of sugarcane fields. Plant Arch. 2010, 10, 667-669.

43. Bogdan, A.V. Tropical Pasture and Fodder Plants; Tropical Agriculture Series; Longman: New York, NY, USA, $1977 ;$ p. 475.

44. Holm, L.; Pancho, J.V.; Herberger, J.P.; Plucknett, D.L. A Geographical Atlas of World Weeds; John Wiley \& Sons: New York, NY, USA, 1979; p. 391.

45. Quattrocchi, U. CRC World Dictionary of Grasses: Common Names, Scientific Names, Eponyms, Synonyms, and Etymology-3 Volume Set; CRC Press Taylor and Francis Group: Boca Raton, FL, USA, 2006; pp. 269-410. [CrossRef]

46. Kalaiyarasi, D. Evaluation of Sulfentrazone for Weed Control in Sugarcane and Its Residual Effect on Succeeding Crops. Ph.D. Thesis, Tamil Nadu Agricultural University, Coimbatore, India, 2012.

47. Moorthy, B.T.S. Effect of methods of land preparation and herbicide use on weed control and crop performance of rainfed upland rice (Oryza sativa) in coastal Orissa. Indian J. Agric. Sci. 1992, 62, 382-386.

48. Abraham, C.T.; Singh, S.P. Control weeds in row crops by intercropping with legumes. Indian Farming 1986, 36, 33-34.

49. Chauhan, B.S. Crowfoot grass (Dactyloctenium aegyptium) germination and response to herbicides in the Philippines. Weed Sci. 2011, 59, 512-516. [CrossRef]

50. Waterhouse, B.M. Know your enemy: Recent records of potentially serious weeds in northern Australia, Papua New Guinea and Papua (Indonesia). Telopea 2003, 10, 477-485. [CrossRef]

51. Intanon, S.; Wiengmoon, B.; Mallory-Smith, C.A. Seed morphology and allelopathy of invasive Praxelis clematidea. Not. Bot. Hort. Agrobot. Cluj. 2020, 48, 261-272. [CrossRef]

52. Khamare, Y.; Marble, S.C.; Boyd, N.S.; Steed, S.T. PRE and POST control of Praxelis clematidea, an emerging weed in Florida nursery production. Weed Technol. 2020, 34, 779-786. [CrossRef]

53. Clayton, W.D.; Vorontsova, M.S.; Harman, K.T.; Williamson, H. Grass Base-The Online World Grass Flora. Available online: http:/ / www.kew.org/data/grasses-db/www/imp07790.htm (accessed on 14 January 2020).

54. IPPC. International Plant Protection Convention of Thailand. Plant pest in Thailand. Pennisetum polystachyon. Available online: http:/ / ippc.acfs.go.th/pest/G001/T010/WEED065 (accessed on 14 June 2020).

55. Galinato, M.I. Upland Rice Weeds of South and Southeast Asia; International Rice Research Institute: Makati City, Philippines, 1999; pp. 156-157.

56. Manidool, C. Brachiaria distachya (PROSEA). Plant Use English. Available online: https://uses.plantnet-project.org/en/ Brachiaria_distachya_(PROSEA) (accessed on 4 June 2020).

57. Wongkaew, P.; Hanboonsong, Y.; Sirithorn, P.; Choosai, C.; Boonkrong, S.; Tinnangwattana, T.; Damak, S. Differentiation of phytoplasmas associated with sugarcane and gramineous weed white leaf disease and sugarcane grassy shoot disease by RFLP and sequencing. Theor. Appl. Genet. 1997, 95, 660-663. [CrossRef]

58. Sarindu, N.; Clark, M.F. Antibody production and identity of MLOs associated with sugarcane whiteleaf disease and bermudagrass whiteleaf disease from Thailand. Plant Pathol. 1993, 42, 396-402. [CrossRef] 
59. Nakashima, K.; Chaleeprom, W.; Wongkaew, P.; Sirithorn, P. Detection of mycoplasma-like organisms associated with white leaf disease of sugarcane in Thailand using DNA probes. JIRCAS J. 1994, 1, 57-67.

60. Nakashima, K.; Hayashi, T.; Chaleeprom, W.; Wongkaew, P.; Sirithorn, P. Complex phytoplasma flora in northeast Thailand as revealed by $16 \mathrm{~S}$ rDNA analysis. Ann. Phytopathol. Soc. Jpn. 1996, 62, 57-60. [CrossRef]

61. Manidool, C. Brachiaria distachya (L.) Stapf. Record from Proseabase; Mannetje, L., Jones, R.M., Eds.; PROSEA (Plant Resources of South-East Asia) Foundation: Bogor, Indonesia; Available online: http:/ / proseanet.org/prosea/e-prosea_detail.php?frt=\&id=18 44 (accessed on 4 June 2020).

62. Santos, F.; Borém, A.; Caldas, C. (Eds.) Sugarcane: Agricultural Production, Bioenergy and Ethanol; Academic Press: Cambridge, UK, 2015; pp. 148-150.

63. Richardson, F.E. Injury to sugarcane by 2, 4-D formulations. S. Afr. Sugar Technol. Assoc. 1969, 43, 122-129.

64. Richard, E.P., Jr. Response of sugarcane (Saccharum sp.) cultivars to preemergence herbicides. Weed Technol. $1989,3,358-363$. [CrossRef]

65. Zhang, J.; Zheng, L.; Jäck, O.; Yan, D.; Zhang, Z.; Gerhards, R.; Ni, H. Efficacy of four post-emergence herbicides applied at reduced doses on weeds in summer maize (Zea mays L.) fields in North China Plain. Crop Prot. 2013, 52, 26-32. [CrossRef] 